\section{Psykoterapeuten viktigere enn hva slags metode?}

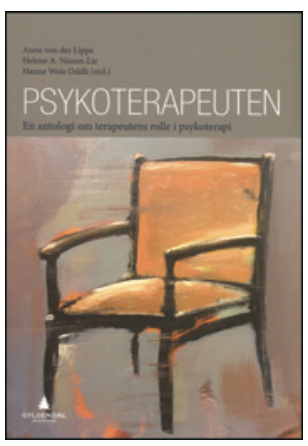

Anna von der Lippe, Helene A. Nissen-Lie, Hanne Weie Oddli, red.

\section{Psykoterapeuten}

En antologi om terapeutens rolle

i psykoterapi. 323 s, tab, ill. Oslo: Gyldendal

Akademisk, 2014. Pris NOK 469

ISBN 978-82-05-47213-6

To viktige funn i psykoterapiforskningen: 1) Det er minimale forskjeller på effekten av ulike veletablerte psykoterapimetoder (psykodynamisk terapi, kognitiv atferdsterapi, dialektisk atferdsterapi, mentaliseringsbasert terapi osv.), 2) men det er stor forskjell på hva ulike terapeuter oppnår med bruk av én og samme metode (som med antidepressiver!). Terapeutens væremåte og bruk av kunnskap synes altså å være viktigere enn hvilken spesifikke metode som brukes. Kvaliteten på terapeutens intervensjon kan være avgjørende. Hva som kjennetegner den virksomme terapeut og dennes atferd, er dermed (igjen) blitt et viktig forskningsfelt. Denne boken tar mål av seg til å oppsummere kunnskapsstatus på dette feltet, og lykkes godt med det.

Boken består av fire deler. I den første oppsummerer to av «stjernene» i internasjonal psykoterapiforskning, David Orlinski og Bruce Wampold, hva vi nå vet om terapeutens bidrag i sammenheng med andre sentrale endringsfaktorer i psykoterapi, og hva som kjennetegner vellykkede psykoterapeuter. I del 2, kalt «Terapeutens profesjonelle rolle», drøftes sentrale temaer som hvordan erfarne terapeuter bruker kunnskap og håndterer kliniske utfordringer som motoverføring, ikke-verbalt samspill, håp og håpløshet, og om intervensjonene den første timen kan varsle noe om utfallet. Del 3 tar for seg psykoterapeutens utviklingsprosess, psykoterapiveiledningens betydning og en modell for studenters og terapeuters egenutvikling. I den siste delen er temaet både hvorfor noen velger å bli psykoterapeut, og hva et langt faglig liv som terapeut har gjort med behandlerens eget liv. Til slutt fokuseres det meget betimelig på utfordringen som ligger i å anvende kunnskap innhentet på gruppenivå overfor den enkelte pasient.

De femten forfatterne er alle psykologer. De skriver kort, konsist og med sentrale poenger som også belyses med gode kliniske vignetter der det er adekvat. Det er få gjentakelser, og redaktørene har hatt en god hånd med sine medarbeidere. Mange formidler resultater fra egen, fersk forskning. Eksemplene integrerer psykodynamisk og kognitiv forståelse på et eksemplarisk sett. Boken er tilegnet professor Michael Rønnestad, som gjennom mange år har gjort en fremragende innsats for å øke vår forståelse av hvordan prosessen hos gode menneskebehandlere pågår over år, og hva som er de viktigste forutsetningene for dette. Han kan være stolt av sine kolleger og elever.

Boken kan ha én uheldig bivirkning. Den kan forlede leseren til å tro at psykoterapi er en behandlingsform som bare psykologer, og ikke leger, driver med - ikke bare legene Freud, Beck, Kernberg og Bateman, men alle psykiatere og barnepsykiatere, mange fastleger, onkologer og pediatere. Denne utgivelsen er derfor i høyeste grad av interesse også for dem.

\section{Per Vaglum}

Professor emeritus, Avdeling for medisinsk atferdsvitenskap Universitetet i Oslo

\section{Viktig bok med dokumentasjon av erfaringer med kriser}

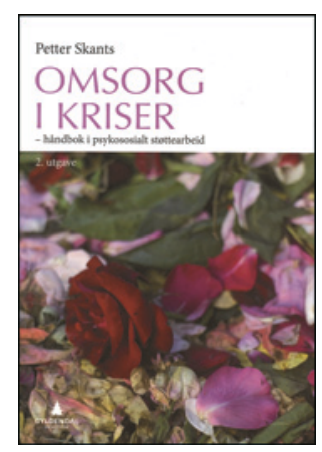

\section{Petter Skants Omsorg i kriser}

Håndbok i psykososialt støttearbeid. 2. utg. 259 s, ill. Oslo: Gyldendal Akademisk, 2014 Pris NOK 385 ISBN 978-82-05-46713-2

Sjømannskirken har gjennom 150 år fått erfaring med hvordan møte mennesker i krise i utlandet. Denne boken kan anbefales som en god håndbok for dem som skal lage beredskapsplaner for bedrifter, organisasjoner, utenrikstjenesten eller kommuner, både i Norge og i utlandet. Den gir en god oversikt over hvordan man kan møte mennesker rammet av alvorlige hendelser som ulykker, kriser eller katastrofer.

De faglige rådene er godt begrunnet ut fra dagens kunnskap om forståelse av krisereaksjoner, og hva som hjelper. Boken dekker relevante temaer. Den er praktisk og kan brukes som oppslagsverk, og det er enkelt å finne nyttig informasjon i bokens 12 kapitler og i vedlegg ( 45 s.). Her er flere nyttige tips i sjekklister for bl.a. varsling, risiko- og sårbarhetsanalyse, telefonsamtaler samt ulike liturgier/program for markeringer. Det vises eksempel på skriftlig materiell til utdeling til de rammede, f.eks. om normale reaksjoner på kriser (norsk og engelsk). Boken beskriver også betydningen av kunnskap om redning, ivaretakelse og kommunikasjon når det oppstår akutte kriser. Menneskets behov for å ha kontroll, å bli sett og bekreftet og å se sammenhenger vektlegges som sentralt i den psykososiale oppfølgingen. Personlig synes jeg ikke uttrykket «tre psykologiske motorer» passer så godt.

Det fenomenet at personlige forhold påvirker både opplevelsen av å bli rammet av en krise og den hjelpen man yter andre i krise, er godt forklart. «Støttearbeid handler om å orke, og tørre, å være sammen med mennesker som har det vondt, mens de har det vondt.» Det var lærerikt å lese beskrivelsen av en rekke ulike offentlige og private aktører som kan være involvert $\mathrm{i}$ krisearbeid både i Norge og i utlandet. Forventningene om hjelp i utlandet ble mer tydelig etter flodbølgekatastrofen 2. juledag 2004, noe som førte til endring av sentrale nasjonale retningslinjer og lovverk. Et godt planverk er en sentral forutsetning for at mennesker rammet av kriser og ulykker blir møtt med omsorg og ivaretakelse. Forfatteren fremhever betydningen av planlegging av øvelser. Samarbeid og informasjonsarbeid kan være sårbare ledd. Hva psykososial kriseledelse må ha oppmerksomheten rettet mot, bruk av sosiale medier i informasjonsarbeidet og innholdet i den psykososiale oppfølgingen er godt forklart. Det vises til erfaringer med planlegging av kollektive markeringer, minnemarkeringer, ulike ritualer og samarbeid med personer fra ulike kulturer.

De ulike begrepene kunne vært samlet på ett sted. Temaet selvmord er noe overflatisk beskrevet, og diagnosen posttraumatisk stresslidelse (PTSD) er litt upresist forklart. Likevel: Dette er en gjennomarbeidet og god bok, preget av Sjømannskirkens erfaringer med omsorg for personer rammet av krise!

\section{Eva Try}

Psykiatrisk sykepleier, Helse Bergen

Kronstad distriktpsykiatriske senter 